\title{
Recent advances in understanding non-celiac gluten
}

\section{sensitivity [version 1; peer review: 2 approved]}

\section{Maria Raffaella Barbaro, Cesare Cremon (D), Vincenzo Stanghellini, Giovanni Barbara}

Department of Medical and Surgical Sciences (DIMEC) and Center for Applied Biomedical Research (CRBA), Alma Mater Studiorum University of Bologna and S. Orsola-Malpighi Hospital, Bologna, Italy

V1 First published: 11 Oct 2018, 7(F1000 Faculty Rev):1631

https://doi.org/10.12688/f1000research.15849.1

Latest published: 11 Oct 2018, 7(F1000 Faculty Rev):1631

https://doi.org/10.12688/f1000research.15849.1

\section{Abstract}

Non-celiac gluten sensitivity (NCGS) is a condition characterized by intestinal and extra-intestinal symptoms related to the ingestion of gluten-containing foods in the absence of celiac disease and wheat allergy. The diagnosis is cumbersome and currently confirmed only by gluten withdrawal and double-blind placebo challenge protocols. There is great overlap in symptoms between NCGS and other functional gastrointestinal disorders, making a differential diagnosis difficult. The pathophysiology of NCGS is largely unclear, and there are contrasting data on the trigger of this condition. This review will highlight the state-of-the-art knowledge on NCGS and the key open questions.

\section{Keywords}

NCGS, gluten, wheat, diagnosis, IBS

\section{Open Peer Review \\ Approval Status \\ 1 \\ 2 \\ version 1 \\ 11 Oct 2018 \\ Faculty Reviews are review articles written by the prestigious Members of Faculty Opinions. The articles are commissioned and peer reviewed before publication to ensure that the final, published version is comprehensive and accessible. The reviewers who approved the final version are listed with their names and affiliations.}

1. Carlo Catassi, Marche Polytechnic University, Ancona, Italy

2. Knut E A Lundin, University of Oslo, Oslo, Norway

Any comments on the article can be found at the end of the article. 
Corresponding author: Giovanni Barbara (giovanni.barbara@unibo.it)

Author roles: Barbaro MR: Conceptualization, Writing - Original Draft Preparation, Writing - Review \& Editing; Cremon C: Writing Review \& Editing; Stanghellini V: Writing - Review \& Editing; Barbara G: Conceptualization, Funding Acquisition, Writing - Original Draft Preparation, Writing - Review \& Editing

Competing interests: No competing interests were disclosed.

Grant information: The study was supported in part by the Italian Ministry of Education, University, and Research and by the University of Bologna RFO to GB. GB is a recipient of an educational grant from Fondazione del Monte di Bologna e Ravenna (Bologna, Italy). The funders had no role in study design, data collection and analysis, decision to publish, or preparation of the manuscript.

Copyright: @ 2018 Barbaro MR et al. This is an open access article distributed under the terms of the Creative Commons Attribution License, which permits unrestricted use, distribution, and reproduction in any medium, provided the original work is properly cited.

How to cite this article: Barbaro MR, Cremon C, Stanghellini V and Barbara G. Recent advances in understanding non-celiac gluten sensitivity [version 1; peer review: 2 approved] F1000Research 2018, 7(F1000 Faculty Rev):1631

https://doi.org/10.12688/f1000research.15849.1

First published: 11 Oct 2018, 7(F1000 Faculty Rev):1631 https://doi.org/10.12688/f1000research.15849.1 


\section{Introduction}

Non-celiac gluten sensitivity (NCGS) is a condition characterized by intestinal and extra-intestinal symptoms triggered by the introduction of gluten-containing foods ${ }^{1}$. Despite the efforts that have been made, this condition remains ill defined. It is still a matter of debate whether NCGS is caused by gluten or other components of wheat. The prevalence rate of NCGS is unknown but is suspected to be higher than that of celiac disease. In the absence of a reliable biomarker, confirmation of an NCGS diagnosis can be made only with a double-blind placebocontrolled (DBPC) gluten challenge. However, this procedure is complex and of limited applicability in routine clinical practice. In the absence of diagnostic markers, distinguishing NCGS from functional gastrointestinal (GI) diseaseprincipally, irritable bowel syndrome (IBS) - is a challenge. In this review, we discuss recent advances in the pathophysiology, epidemiology, diagnosis, and treatment of NCGS.

\section{Definition and epidemiology}

NCGS is a condition characterized by intestinal and extraintestinal symptoms related to the ingestion of gluten-containing foods in patients in whom celiac disease and wheat allergy have been excluded ${ }^{1}$. Some authors indicated that the terminology "non-celiac wheat sensitivity" is more appropriate, as components other than gluten could be implicated in symptom experience. Although NCGS has been suggested to be the most common gluten-related disorder, its prevalence remains unknown because of a lack of diagnostic markers. According to selfreported data, the prevalence rate of NCGS ranges between $0.5 \%$ and $13 \%$ in the general population ${ }^{2-5}$, and prevalence is higher in women ${ }^{2,3}$, teenagers, and patients in the third to fourth decade of life $\mathrm{e}^{2,4}$.

\section{Pathophysiology}

The pathophysiology of NCGS is largely undetermined, as most studies were performed in patients in whom symptoms were self-reported. Under these circumstances, NCGS remains a subjective diagnosis influenced by nocebo response. With these limitations, some studies have investigated the implication of wheat components and possible mechanisms underlying bowel dysfunction and symptom generation. It has been suggested that gluten is not the only trigger of symptoms in NCGS. Other components include amylase-trypsin inhibitors (ATIs) and fermentable oligo-, di-, and mono-saccharides and polyols (FODMAPs).

\section{Gluten}

Gluten proteins represent the major storage proteins of wheat, barley, and rye which are in the endosperm of the grains. Gluten proteins are prolamins and are rich in glutamine and proline and have different names according to grain species, including (a) gliadins (monomers) and glutenins (polymers) in wheat, (b) hordeins in barley, and (c) secalins in rye ${ }^{6}$. After ingestion, gluten is hydrolyzed by GI proteases, but the abundance of glutamine and proline residues produces incomplete gluten digestion. Previous studies have shown that gliadin, even in healthy subjects, can determine a prompt and transient increase in gut permeability which is related to the amount of the peptide ingested with the diet ${ }^{7,8}$. The increase in intestinal permeability is thought to be the consequence of binding of gliadin to the CXCR3 chemokine receptor. This in turn determines the release of zonulin, a facilitator of interepithelial tight junction opening. These observations have been made in single centers and need to be confirmed. In turn, the passage of indigested peptides through the epithelium increases, resulting in over-stimulation of the immune system in the lamina propria. Glutamine and proline are the preferred substrate of mucosal tissue transglutaminases (tTGs). The result of tTG enzymatic breakdown generates peptides with a great affinity for major histocompatibility complex II (MHC II), which strongly stimulate the immune system in HLA-DQ2/8-positive subjects ${ }^{9}$. In celiac disease, at least, the antigen presentation to $\mathrm{T}$ cells induces innate and adaptive responses that culminate in villus atrophy, crypt hyperplasia, and enhanced infiltration of intra-epithelial lymphocytes ${ }^{10,11}$.

The role of gluten as a trigger of NCGS symptoms is supported by different lines of evidence. Di Sabatino et al. performed a randomized, placebo-controlled, crossover trial in 59 patients with self-diagnosed gluten sensitivity and demonstrated that symptoms are worse in patients challenged with gluten $(4.375 \mathrm{~g})$ compared with those challenged with placebo ${ }^{12}$. In a large trial including patients with functional GI symptoms, $14 \%$ of these were diagnosed with NCGS and had symptom worsening during a $5.6 \mathrm{~g} /$ day challenge of gluten ${ }^{13}$. In a pediatric population of 1,114 children with functional GI symptoms negative for celiac disease and wheat allergy, 28 patients self-reporting NCGS performed a double-blind gluten (10 g/day) challenge and 11 patients (39\%) were NCGS positive. These data showed that gluten challenge-confirmed NCGS is not rare in children who have functional bowel disorders ${ }^{14}$. However, others have suggested that in case of a high nocebo effect, the methodology used to define NCGS should be chosen carefully ${ }^{15}$. In a controlled study, only one-third of patients with self-reported NCGS had confirmation of the diagnosis with a double-blind gluten challenge, suggesting that most patients with selfreported diagnosis should not be labeled as NCGS. Interestingly, only one-third of these patients classified as NCGS could recognize the flour containing gluten ${ }^{16}$. The effect of gluten and fructans on symptoms was evaluated in individuals with self-reported NCGS, and no effect of gluten emerged compared with placebo ${ }^{17}$.

\section{FODMAPS}

FODMAPs are part of wheat and may play a role in NCGS pathophysiology and symptom development. In a placebocontrolled crossover re-challenge study, it was found that GI symptoms improved during reduced FODMAP intake and worsened with gluten or whey protein. The effect of gluten on symptoms was observed in only $8 \%$ of subjects. These data suggest that most effects described as gluten related in patients with NCGS could in fact be determined by the presence of other components contained in wheat, including FODMAPs ${ }^{18}$. A more recent article demonstrated that two weeks of a lowFODMAP diet in patients with self-reported NCGS significantly improved symptoms. In addition, this study showed that two 
weeks of a gluten-free diet (GFD) induced a symptom reduction compared with that reported during the low-FODMAP diet $^{19}$. Attention has been directed to fructans, a component of FODMAPs. In a controlled challenge with gluten, fructans, or placebo, it was shown that the highest symptom scores were recorded during fructan challenge but that no difference emerged between gluten and placebo ${ }^{17}$.

\section{Amylase-trypsin inhibitors}

Gluten represents $80 \%$ to $90 \%$ of the total amount of grain proteins. The remaining $10 \%$ to $20 \%$ is represented by albumins and globulins. ATIs, which represent up to $4 \%$ of total protein, are major allergens in baker's asthma ${ }^{20}$ and activators of the innate immune response in vitro and in vivo ${ }^{21}$. ATIs induce intestinal infiltration and activation of myeloid cells and the release of inflammatory cytokines. Interestingly, the amount of ATIs is increased in modern hexaploid wheat, rye, and barley compared with older wheat variants ${ }^{22}$. Zevallos et al. demonstrated that ATIs are highly resistant to proteases and heat, activate Toll-like receptor-4, and can evoke intestinal inflammation by activating gut and mesenteric lymph node myeloid cells ${ }^{22}$. Based on this evidence, it has been suggested that ATIs may contribute to the activation of innate immune cells in low-level pre-existing small intestinal and colonic inflammation and could have a role in the pathophysiology of NCGS ${ }^{22}$.

\section{Clinical presentation}

In general, symptoms in patients with NCGS appear with the ingestion of gluten and disappear or ameliorate with gluten avoidance. The re-introduction of gluten with diet or gluten challenge determines symptom reappearance. The main symptoms in patients with NCGS include abdominal bloating and pain in the upper or lower abdomen, diarrhea, nausea, aphthous stomatitis, alternating bowel habits, and constipation. These symptoms are also common in other functional GI disorders, particularly IBS and functional dyspepsia. Differentiation of NCGS from functional symptoms represents a challenge for clinicians. For this reason, some authors argue that, in the absence of a reliable biomarker, NCGS may not exist as a distinct clinical entity and that symptom experience is the result of symptoms worsening with diet, as often occurs in IBS or dyspepsia. In addition to experiencing GI symptoms, patients with NCGS most often experience a complex of extra-intestinal symptoms, including a "foggy mind", which is described as an inability to concentrate, reduction of mnemonic capabilities, and lack of well-being as well as tiredness, headache, anxiety, numbness, joint/muscle pain, and skin rash/dermatitis ${ }^{23}$.

\section{Diagnosis}

The diagnosis of NCGS remains elusive because of poor knowledge of the mechanisms underlying symptom experience and the lack of reliable biomarkers. According to the Salerno consensus conference, the gold standard for the diagnosis of NCGS is based on a DBPC crossover gluten challenge'. This diagnostic process is complex and remains unfeasible in daily clinical practice.

It is still unclear whether patients with a diagnosis of NCGS should follow a GFD for life. This is particularly relevant in light of the fact that intestinal and extra-intestinal symptoms may persist in around $70 \%$ of patients after one year of $\mathrm{GFD}^{24}$. It is still unclear whether gluten reduction, rather than avoidance, would be enough to control symptoms. Some authors have criticized the efficacy of DBPC in identifying patients with NCGS. Molina-Infante and Carroccio analyzed data from 10 DBPC gluten challenge trials comprising 1,312 adults and demonstrated that only $16 \%$ of patients showed gluten-specific symptoms and $40 \%$ of these subjects had a nocebo response. This evidence reveals heterogeneity and potential methodology flaws among studies of gluten challenge ${ }^{5}$.

\section{Differential diagnosis}

The differential diagnosis for NCGS should focus on celiac disease, wheat allergy, and functional GI syndromes such as IBS. The diagnoses of celiac disease and wheat allergy are discussed in detail in previous comprehensive reviews and will not be discussed further ${ }^{25,26}$.

Symptoms of NCGS overlap with those of IBS. In the absence of valid biomarkers, differential diagnosis between the two conditions is not always feasible in daily clinical practice (Figure 1). Gluten, the key determinant factor in NCGS, is sometimes identified by patients with IBS as a major trigger of symptoms ${ }^{27,28}$. In a UK study evaluating the prevalence of self-reported NCGS, it was found that individuals with gluten sensitivity fulfilled the Rome III criteria for IBS to a greater extent than those without gluten sensitivity $(20 \% \text { versus } 4 \%)^{29}$. Carroccio et al. showed that one-third of patients with IBS undergoing a DBPC wheat challenge were sensitive to wheat ${ }^{23}$. A randomized DBPC gluten re-challenge trial in patients with IBS demonstrated that gluten significantly worsened overall symptoms, abdominal pain, abdominal bloating, tiredness, and satisfaction with stool consistency. Symptom improvement was not associated with HLA genotype ${ }^{30}$. Compared with IBS, NCGS is characterized by a greater incidence of anemia ${ }^{23}$, weight $\operatorname{loss}^{23}$, atopy ${ }^{31}$, and anti-gliadin (AGA) $\operatorname{IgG}$ antibody ${ }^{32}$. The HLA-DQ2/8 phenotype has been reported to be variable, from $24 \%$ to $100 \%$, in patients with $\mathrm{NCGS}^{5}$. Vazquez-Roque et al. performed a randomized controlled trial of a glutencontaining diet (GCD) or GFD in patients with IBS with diarrhea (IBS-D) and showed that GCD was associated with increased small bowel permeability and decreased tight junction expression in the colonic mucosa ${ }^{33}$. In addition, the effect of gluten on epithelial permeability was greater in HLA-DQ2/8positive patients ${ }^{33}$. Using confocal laser endomicroscopy, Fritscher-Ravens et al. showed that wheat challenge in the duodenal mucosa of IBS-D patients with suspected wheat intolerance induced an increase in intra-epithelial lymphocytes, epithelial breaks, and inter-villous spaces ${ }^{34}$. These data suggest that wheat can determine morphological changes in the intestinal wall of patients with self-reported wheat intolerance. A recent systematic review evaluated the efficacy of exclusion diet in IBS by the examination of randomized controlled trials. Nine studies turned out to be eligible. A GFD was evaluated in two studies and was associated with a reduction of global symptoms compared with a control diet (relative risk $=0.42$ ), although the statistical significance was not reached. The remaining seven studies evaluated the efficacy of a low-FODMAP diet compared 


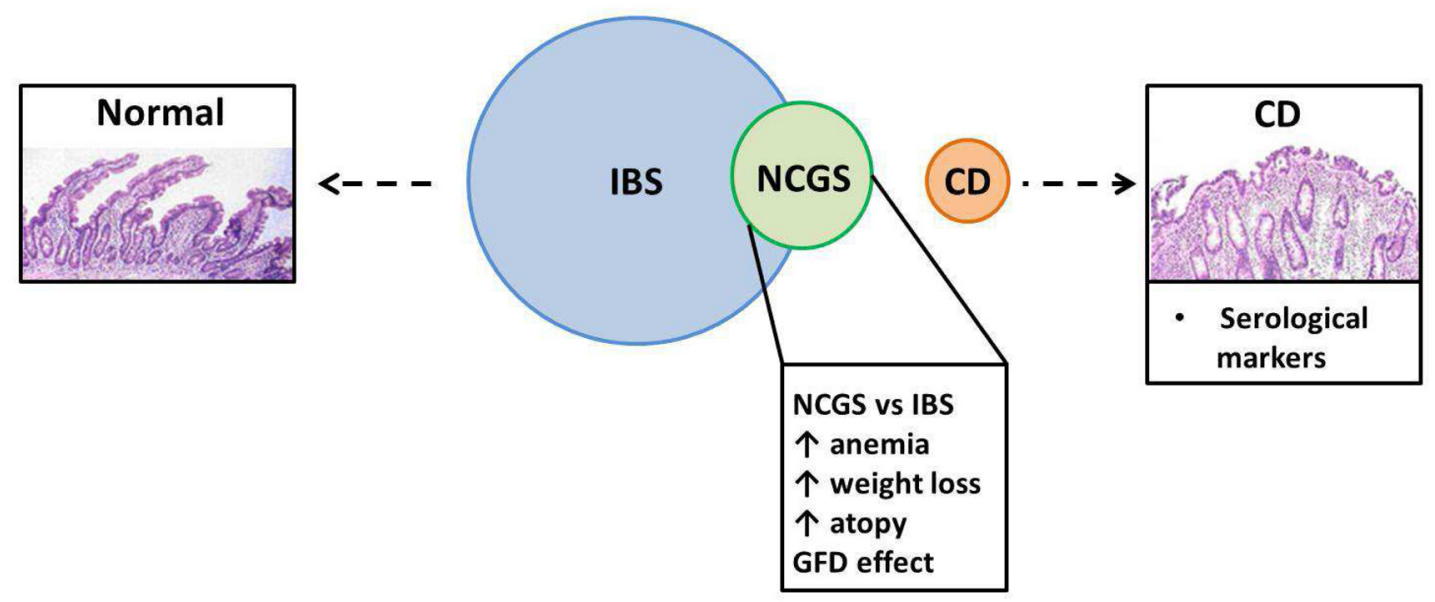

Figure 1. Overlap and differences between irritable bowel syndrome (IBS), non-celiac gluten sensitivity (NCGS), and celiac disease (CD). There is an overlap in symptoms between NCGS and IBS patients, although there are also some differences. NCGS symptoms improve after a gluten-free diet (GFD). In addition, NCGS is associated with a greater incidence of anemia, and weight loss and atopy are more common in patients with NCGS than in patients with IBS. NCGS could be considered a partially separated entity from IBS but is completely distinct from CD for serological and histological manifestations.

with different control interventions; only three of these studies used rigorous control diets and showed the least magnitude of effect. The authors concluded that based on the available data there is insufficient evidence to recommend a GFD or lowFODMAP diet in patients with IBS $^{35}$.

\section{Identification of putative biomarkers}

Biomarkers are objectively measurable indicators of normal or pathological processes or pharmacological responses to a therapeutic intervention ${ }^{36}$. The identification of an NCGS biomarker would represent an important advancement in the field of NCGS, as it would legitimize NCGS and advance diagnosis with the identification of relevant subgroups of patients responding to GFD.

For the time being, no valid biomarkers have been characterized, although some efforts have been made. Between $25 \%$ and $56 \%$ of subjects with self-reported NCGS had positive ( $>50$ arbitrary units) AGA IgG antibodies ${ }^{32,37}$. However, these studies were uncontrolled, as the prevalence of AGA IgG positivity in a healthy control group was not assessed ${ }^{32,37}$. In addition, others have provided contradictory results ${ }^{30,38}$. Uhde et al. showed that NCGS is characterized by significant increased serum levels of soluble CD14, lipopolysaccharide-binding protein, and bacterial-directed antibodies (that is, flagellin), suggesting a systemic immune activation to microbial components ${ }^{39}$. The same study, though not controlled against IBS, reported increased levels of a marker of epithelial integrity (that is, fatty acid-binding protein 2) which correlated with the markers of systemic immune activation, suggesting that mucosal barrier dysfunction may participate in $\mathrm{NCGS}^{39}$. Notably, this last piece of evidence is in line with previous data showing epithelial barrier dysfunction in tissue explants obtained from gluten-related disorders ${ }^{40}$. In contrast, no alteration in the lactulose/mannitol test was observed in patients with $\mathrm{NCGS}^{41}$. Other mucosal abnormalities that would differentiate NCGS from other conditions such as IBS include a mild increase in intra-epithelial lymphocytes ${ }^{41,42}$, increased interferon-gamma gene expression ${ }^{42}$, increased goblet cell number ${ }^{19}$, and changes in Bacteroidetes-to-Firmicutes ratios ${ }^{19}$.

\section{Conclusions}

NCGS is an increasingly recognized clinical entity characterized by intestinal and extra-intestinal symptoms related to the ingestion of gluten-containing foods in patients in whom celiac disease and wheat allergy have been excluded. Clinically, NCGS is often indistinguishable from functional GI disorders and primarily from IBS. According to double-blind controlled studies, it appears that NCGS is overemphasized. The identification of reliable tests that could be used in clinical practice would enormously improve the recognition, legitimization, and treatment of this disorder.

\section{Abbreviations}

AGA, anti-gliadin; ATI, amylase-trypsin inhibitor; DBPC, doubleblind placebo-controlled; FODMAPs, fermentable oligosaccharides, disaccharides, and monosaccharides and polyols; GCD, gluten-containing diet; GFD, gluten-free diet; GI, gastrointestinal; HLA, human leukocyte antigen; IBS, irritable bowel syndrome; IBS-D, irritable bowel syndrome with diarrhea; NCGS, non-celiac gluten sensitivity; tTG, tissue transglutaminase

\section{Grant information}

The study was supported in part by the Italian Ministry of Education, University, and Research and by the University of Bologna RFO to GB. GB is a recipient of an educational grant from Fondazione del Monte di Bologna e Ravenna (Bologna, Italy).

The funders had no role in study design, data collection and analysis, decision to publish, or preparation of the manuscript. 
1. F Catassi C, Elli L, Bonaz B, et al:: Diagnosis of Non-Celiac Gluten Sensitivity (NCGS): The Salerno Experts' Criteria. Nutrients. 2015; 7(6): 4966-77. PubMed Abstract | Publisher Full Text | Free Full Text | F1000 Recommendation

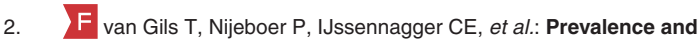
Characterization of Self-Reported Gluten Sensitivity in The Netherlands. Nutrients. 2016; 8(11): pii: E714.

PubMed Abstract | Publisher Full Text | Free Full Text | F1000 Recommendation

3. F Cabrera-Chávez F, Dezar GV, Islas-Zamorano AP, et al:: Prevalence of Self-Reported Gluten Sensitivity and Adherence to a Gluten-Free Diet in Argentinian Adult Population. Nutrients. 2017; 9(1): pii: E81. PubMed Abstract | Publisher Full Text | Free Full Text | F1000 Recommendation

4. F Carroccio A, Giambalvo O, Blasca F, et al:: Self-Reported Non-Celiac Wheat Sensitivity in High School Students: Demographic and Clinical Characteristics. Nutrients. 2017; 9(7): pii: E771.

PubMed Abstract | Publisher Full Text | Free Full Text | F1000 Recommendation

5. Molina-Infante J, Carroccio A: Suspected Nonceliac Gluten Sensitivity Confirmed in Few Patients After Gluten Challenge in Double-Blind, Placebo-Controlled Trials. Clin Gastroenterol Hepatol. 2017; 15(3): 339-348. PubMed Abstract | Publisher Full Text

6. Balakireva AV, Zamyatnin AA: Properties of Gluten Intolerance: Gluten Structure, Evolution, Pathogenicity and Detoxification Capabilities. Nutrients. 2016; 8(10): pii: E644.

PubMed Abstract | Publisher Full Text | Free Full Text

7. Silano M, Vincentini O, De Vincenzi M: Toxic, immunostimulatory and antagonist gluten peptides in celiac disease. Curr Med Chem. 2009; 16(12): 1489-98. PubMed Abstract | Publisher Full Text

8. Picarelli A, Di Tola M, Sabbatella L, et al:: 31-43 amino acid sequence of the alpha-gliadin induces anti-endomysial antibody production during in vitro challenge. Scand J Gastroenterol. 1999; 34(11): 1099-102. PubMed Abstract | Publisher Full Text

9. Schuppan D: Current concepts of celiac disease pathogenesis. Gastroenterology. 2000; 119(1): 234-42.

PubMed Abstract | Publisher Full Text

10. Maiuri L, Ciacci C, Ricciardelli I, et al:: Association between innate response to gliadin and activation of pathogenic T cells in coeliac disease. Lancet. 2003; 362(9377): 30-7.

PubMed Abstract | Publisher Full Text

11. F Frossi B, Tripodo C, Guarnotta C, et al:: Mast cells are associated with the onset and progression of celiac disease. J Allergy Clin Immunol. 2017; 139(4): 1266-1274.e1.

PubMed Abstract | Publisher Full Text | F1000 Recommendation

12. $F$ Di Sabatino A, Volta U, Salvatore C, et al.: Small Amounts of Gluten in Subjects With Suspected Nonceliac Gluten Sensitivity: A Randomized, DoubleBlind, Placebo-Controlled, Cross-Over Trial. Clin Gastroenterol Hepatol. 2015; 13(9): 1604-12.e3

PubMed Abstract | Publisher Full Text | F1000 Recommendation

13. F Elli L, Tomba C, Branchi F, et al:: Evidence for the Presence of Non-Celiac Gluten Sensitivity in Patients with Functional Gastrointestinal Symptoms: Results from a Multicenter Randomized Double-Blind Placebo-Controlled Gluten Challenge. Nutrients. 2016; 8(2): 84.

PubMed Abstract | Publisher Full Text | Free Full Text | F1000 Recommendation

14. F Francavilla R, Cristofori F, Verzillo $L$, et al: Randomized Double-Blind Placebo-Controlled Crossover Trial for the Diagnosis of Non-Celiac Gluten Sensitivity in Children. Am J Gastroenterol. 2018; 113(3): 421-30. PubMed Abstract | Publisher Full Text | F1000 Recommendation

15. F Gibson PR, Lundin KEA, Guandalini S: Is Non-Celiac Rice-Starch Sensitivity as Common in Children as Non-Celiac Gluten Sensitivity? Am J Gastroenterol. 2018; 113(8): 1254

PubMed Abstract | Publisher Full Text | F1000 Recommendation

16. F Zanini B, Baschè R, Ferraresi A, et al:: Randomised clinical study: gluten challenge induces symptom recurrence in only a minority of patients who meet clinical criteria for non-coeliac gluten sensitivity. Aliment Pharmacol Ther 2015; 42(8): 968-76.

PubMed Abstract | Publisher Full Text | F1000 Recommendation

17. F Skodje GI, Sarna VK, Minelle IH, et al.: Fructan, Rather Than Gluten, Induces Symptoms in Patients With Self-Reported Non-Celiac Gluten Sensitivity. Gastroenterology. 2018; 154(3): 529-539.e2.

PubMed Abstract | Publisher Full Text | F1000 Recommendation

18. Biesiekierski JR, Peters SL, Newnham ED, et al.: No effects of gluten in patients with self-reported non-celiac gluten sensitivity after dietary reduction of fermentable, poorly absorbed, short-chain carbohydrates. Gastroenterology 2013; 145(2): 320-8.e1-3.

PubMed Abstract | Publisher Full Text

19. F Dieterich W, Schuppan D, Schink M, et al.: Influence of low FODMAP and gluten-free diets on disease activity and intestinal microbiota in patients with non-celiac gluten sensitivity. Clin Nutr. 2018; pii: S0261-5614(18)30129-8. PubMed Abstract | Publisher Full Text | F1000 Recommendation

20. Gómez L, Martín E, Hernández D, et al:: Members of the alpha-amylase inhibitors family from wheat endosperm are major allergens associated with baker's asthma. FEBS Lett. 1990; 261(1): 85-8.

PubMed Abstract | Publisher Full Text

21. F Junker $Y$, Zeissig S, Kim SJ, et al.: Wheat amylase trypsin inhibitors drive intestinal inflammation via activation of toll-like receptor 4. J Exp Med. 2012; 209(13): 2395-408.

PubMed Abstract | Publisher Full Text | Free Full Text | F1000 Recommendation

22. F Zevallos VF, Raker V, Tenzer S, et al:: Nutritional Wheat Amylase-Trypsin Inhibitors Promote Intestinal Inflammation via Activation of Myeloid Cells. Gastroenterology. 2017; 152(5): 1100-1113.e12.

PubMed Abstract | Publisher Full Text | F1000 Recommendation

23. F Carroccio A, Mansueto $P$, lacono $G$, et al:: Non-celiac wheat sensitivity diagnosed by double-blind placebo-controlled challenge: exploring a new clinical entity. Am J Gastroenterol. 2012; 107(12): 1898-906; quiz 1907. PublMed Abstract | Publisher Full Text | F1000 Recommendation

24. F Tovoli F, Granito A, Negrini G, et al:: Long term effects of gluten-free diet in non-celiac wheat sensitivity. Clin Nutr. 2017; pii: S0261-5614(17)31437-1. PubMed Abstract | Publisher Full Text | F1000 Recommendation

25. F Leonard MM, Sapone A, Catassi C, et al:: Celiac Disease and Nonceliac Gluten Sensitivity: A Review. JAMA. 2017; 318(7): 647-56. PubMed Abstract | Publisher Full Text | F1000 Recommendation

26. Soares-Weiser $\mathrm{K}$, Takwoingi $Y$, Panesar SS, et al.: The diagnosis of food allergy: a systematic review and meta-analysis. Allergy. 2014; 69(1): 76-86. PubMed Abstract | Publisher Full Text

27. Böhn L, Störsrud S, Törnblom H, et al:: Self-reported food-related gastrointestinal symptoms in IBS are common and associated with more severe symptoms and reduced quality of life. Am J Gastroenterol. 2013; 108(5): 634-41.

PubMed Abstract | Publisher Full Text

28. Monsbakken KW, Vandvik PO, Farup PG: Perceived food intolerance in subjects with irritable bowel syndrome-- etiology, prevalence and consequences. Eur $J$ Clin Nutr. 2006; 60(5): 667-72.

PubMed Abstract | Publisher Full Text

29. Aziz I, Lewis NR, Hadjivassiliou M, et al.: A UK study assessing the population prevalence of self-reported gluten sensitivity and referral characteristics to secondary care. Eur J Gastroenterol Hepatol. 2014; 26(1): 33-9. PubMed Abstract | Publisher Full Text

30. Biesiekierski JR, Newnham ED, Irving PM, et al: Gluten causes gastrointestinal symptoms in subjects without celiac disease: a double-blind randomized placebo-controlled trial. Am J Gastroenterol. 2011; 106(3): 508-14; quiz 515. PubMed Abstract | Publisher Full Text

31. Carroccio A, Mansueto P, D'Alcamo A, et al.: Non-celiac wheat sensitivity as an allergic condition: personal experience and narrative review. $A m J$ Gastroenterol. 2013; 108(12): 1845-52; quiz 1853. PubMed Abstract | Publisher Full Text

32. Volta U, Bardella MT, Calabrò A, et al.: An Italian prospective multicenter survey on patients suspected of having non-celiac gluten sensitivity. BMC Med. 2014; 12: 85 .

PubMed Abstract | Publisher Full Text | Free Full Text

33. F Vazquez-Roque MI, Camilleri M, Smyrk T, et al:: A controlled trial of glutenfree diet in patients with irritable bowel syndrome-diarrhea: effects on bowel frequency and intestinal function. Gastroenterology. 2013; 144(5): 903-911.e3. PubMed Abstract | Publisher Full Text | Free Full Text | F1000 Recommendation

34. Fritscher-Ravens A, Schuppan D, Ellrichmann M, et al.: Confocal endomicroscopy shows food-associated changes in the intestinal mucosa of patients with irritable bowel syndrome. Gastroenterology. 2014; 147(5): 1012-20.e4. PubMed Abstract | Publisher Full Text

35. F Dionne J, Ford AC, Yuan Y, et al:: A Systematic Review and Meta-Analysis Evaluating the Efficacy of a Gluten-Free Diet and a Low FODMAPs Diet in Treating Symptoms of Irritable Bowel Syndrome. Am J Gastroenterol. 2018; 113(9): 1290-1300.

PubMed Abstract | Publisher Full Text | F1000 Recommendation

36. Barbara G: IBS: biomarkers for IBS: ready for prime time? Nat Rev Gastroenterol Hepatol. 2015; 12(1): 9-10.

PubMed Abstract | Publisher Full Text

37. Volta $\mathrm{U}$, Tovoli $\mathrm{F}$, Cicola $\mathrm{R}$, et al.: Serological tests in gluten sensitivity (nonceliac gluten intolerance). J Clin Gastroenterol. 2012; 46(8): 680-5. PubMed Abstract | Publisher Full Text

38. $\mathrm{F}$ Infantino $\mathrm{M}$, Manfredi $\mathrm{M}$, Meacci $\mathrm{F}$, et al.: Diagnostic accuracy of anti-gliadin antibodies in Non Celiac Gluten Sensitivity (NCGS) patients: A dual statistical approach. Clin Chim Acta. 2015; 451(Pt B): 135-41.

PublMed Abstract | Publisher Full Text | F1000 Recommendation 
39. F Uhde M, Ajamian M, Caio G, et al: Intestinal cell damage and systemic immune activation in individuals reporting sensitivity to wheat in the absence of coeliac disease. Gut. 2016; 65(12): 1930-7.

PubMed Abstract | Publisher Full Text | Free Full Text | F1000 Recommendation

40. F Hollon J, Puppa EL, Greenwald B, et al.: Effect of gliadin on permeability of intestinal biopsy explants from celiac disease patients and patients with nonceliac gluten sensitivity. Nutrients. 2015; 7(3): 1565-76.

PubMed Abstract | Publisher Full Text | Free Full Text | F1000 Recommendation
41. Sapone A, Lammers KM, Casolaro V, et al.: Divergence of gut permeability and mucosal immune gene expression in two gluten-associated conditions: celiac disease and gluten sensitivity. BMC Med. 2011; 9: 23.

PubMed Abstract | Publisher Full Text | Free Full Text

42. F Brottveit M, Beitnes AC, Tollefsen S, et al:: Mucosal cytokine response after short-term gluten challenge in celiac disease and non-celiac gluten sensitivity. Am J Gastroenterol. 2013; 108(5): 842-50.

PubMed Abstract | Publisher Full Text | F1000 Recommendation 


\section{Open Peer Review}

\section{Current Peer Review Status:}

\section{Editorial Note on the Review Process}

Faculty Reviews are review articles written by the prestigious Members of Faculty Opinions. The articles are commissioned and peer reviewed before publication to ensure that the final, published version is comprehensive and accessible. The reviewers who approved the final version are listed with their names and affiliations.

\section{The reviewers who approved this article are:}

\section{Version 1}

\section{Knut E A Lundin}

Institute of Clinical Medicine, Faculty of Medicine, University of Oslo, Oslo, Norway

Competing Interests: No competing interests were disclosed.

\section{Carlo Catassi}

Department of Pediatrics, Marche Polytechnic University, Ancona, Italy

Competing Interests: No competing interests were disclosed.

The benefits of publishing with F1000Research:

- Your article is published within days, with no editorial bias

- You can publish traditional articles, null/negative results, case reports, data notes and more

- The peer review process is transparent and collaborative

- Your article is indexed in PubMed after passing peer review

- Dedicated customer support at every stage

For pre-submission enquiries, contact research@f1000.com 